\title{
Er:YAG Laser Irradiation of the Microbiological Apical Biofilm
}

\author{
Ângela Toshie ARAKI ${ }^{1}$ \\ Yuji IBRAKI ${ }^{2}$ \\ Tomofumi KAWAKAMI ${ }^{2}$ \\ José Luiz LAGE-MARQUES ${ }^{1,3}$
}

\author{
${ }^{1}$ Department of Endodontics, School of Dentistry, University of São Paulo, São Paulo, SP, Brazil \\ ${ }^{2}$ Department of Operative Dentistry and Endodontology, Health Science University of Hokkaido, Japan \\ ${ }^{3}$ School of Dentistry, University of Taubaté, Taubaté, SP, Brazil
}

\begin{abstract}
One problem in cases of healing-resistant periapical lesions is to eradicate the contamination at the periapical area. This contamination is due to the microbiological biofilm formed by microorganisms and their subproducts lodged in apical third of the root, on both cementum and dentin surface. Paraendodontic surgery consists of the mechanical removal of harmful agents to promote healing and periapical health. The purpose of this study was to assess the results of Er:YAG laser irradiation on the apical root third of newly extracted teeth to eliminate microbial contamination on root apex surface. Apical irradiation was performed with an Er:YAG laser device using an experimental contact tip, at $100 \mathrm{~mJ}, 10 \mathrm{~Hz}, 1 \mathrm{~W}, 39 \mathrm{~J} / \mathrm{cm}^{2}, 3$ times on the target area. SEM analysis showed the elimination of part of the irradiated cementum and the formation of small roughened without exposing the subjacent dentin. Vaporization of the remaining periodontal tissue and removal of microbiological apical biofilm (MAB) were also observed on the irradiated areas. Under the tested conditions and based on the findings of this study, Er:YAG laser may be considered effective for removal of microbiological apical biofilm.
\end{abstract}

Key Words: periapical lesion, biofilm, periapical surgery, laser, Er:YAG.

\section{INTRODUCTION}

A periapical infection results from microorganisms colonizing and settling at the periapex. Endodontic therapy is the first step to treat periapical lesions. However, in some cases periapical lesions persist even after proper treatment and retreatment of root canals (1). Tronstad et al. (2) reported the presence of periapical bacterial biofilm on resistant periapical lesions (3).

Lin et al. (4) suggested that successful treatment is only possible with total removal of the irritating agents. Periapical surgery is indicated for cases with no sign of healing after retreatment (5). When the microbiological flora is not eradicated with apicoectomy (6), apical curettage can be used to remove infected tissue around the apex. However, the removal of infected cementum and surrounding tissue is not easy, which may explain the persistence of a small number of lesions that do not heal even after apical surgery (7). A report on the effect of ruby lasers on dental hard tissue (8) led to several studies on laser applications in dentistry.

Erbium yttrium aluminum garnet (Er:YAG) laser of $2.94 \mu \mathrm{m}$ wavelength is strongly absorbed by water (9). It has been used for various clinical dental treatments with applications on hard tissues such as apicoectomy $(10)$, superficial calculus removal $(11,12)$ apical cementum removal (13) and bactericidal action. This study evaluated Er:YAG laser efficacy on microbiological apical biofilm (MAB) and infected cementum removal.

\section{MATERIAL AND METHODS}

Ten human teeth with periapical lesions extracted at the Department of Oral Surgery of Sapporo 
Medical University were involved gauze soaked in saline and stored in a sterile flask until use.

The teeth were fixed, submerged in a flask with water and irradiated with the laser using an experimental chisel-shaped contact tip of $0.256 \mathrm{~mm}^{2}$ (Morita Co., Kyoto, Japan). This tip presents a specific energy distribution pattern that allows wide and highly diffused irradiation and was designed to provide uniform ablation of the target surface during irradiation and to avoid energy concentration. The irradiation with this tip is about $80 \%$ of energy concentration at the center of the contact surface in comparison to the conventional contact tip. An Erwin (Hoya and Morita Co., Kyoto, Japan) Er:YAG laser device of $2.94 \mu \mathrm{m}$ wavelength was used in this study. The specimens were irradiated with $3.5 \mathrm{~W}$ peak power, $1 \mathrm{~W}$ average power, $100 \mathrm{~mJ}, 10 \mathrm{~Hz}, 39 \mathrm{~J} / \mathrm{cm}^{2}$ 3 times on the apical $3 \mathrm{~mm}$ of the root at an agle of $60^{\circ}$ during approximately $3 \mathrm{~s}$.

The lased specimens were dehydrated in $99.5 \%$ ethanol, critical-point dried (Hitachi-HPC, Hitachi, Tokyo, Japan), supptercoated with gold using an ion coater (Eiko-IB-3, Eiko Engineering, Ibaraki, Japan) and examined under scanning electron microscopy (SEM - X650; Hitachi, Tokyo, Japan) at $25 \mathrm{kV}$.

\section{RESULTS}

The results were based on a morphological analysis of SEM micrographs. Figure 1 shows an Er:YAG laser irradiated area on the apical root third (A) and irradiated and non-irradiated areas with periodontal tissue (B). Morphological changes can be observed on the apical surface with slightly uneven superficial formations (C). The irradiated area at high magnification (3000X) shows vaporization of microbio- logical apical biofilm, periodontal tissue and part of the cementum surface without dentin exposure (D).

At the same magnification (3000X), Figure 2A shows a non-lased area with biofilm firmly attached to root apex surface. surface. Figures $2 \mathrm{~B}$ and $\mathrm{C}$ show the presence of cocci and rods on the root surface in this biofilm layer.

\section{DISCUSSION}

The treatment of postendodontic therapy failures is very difficult because periapical lesions usually do not
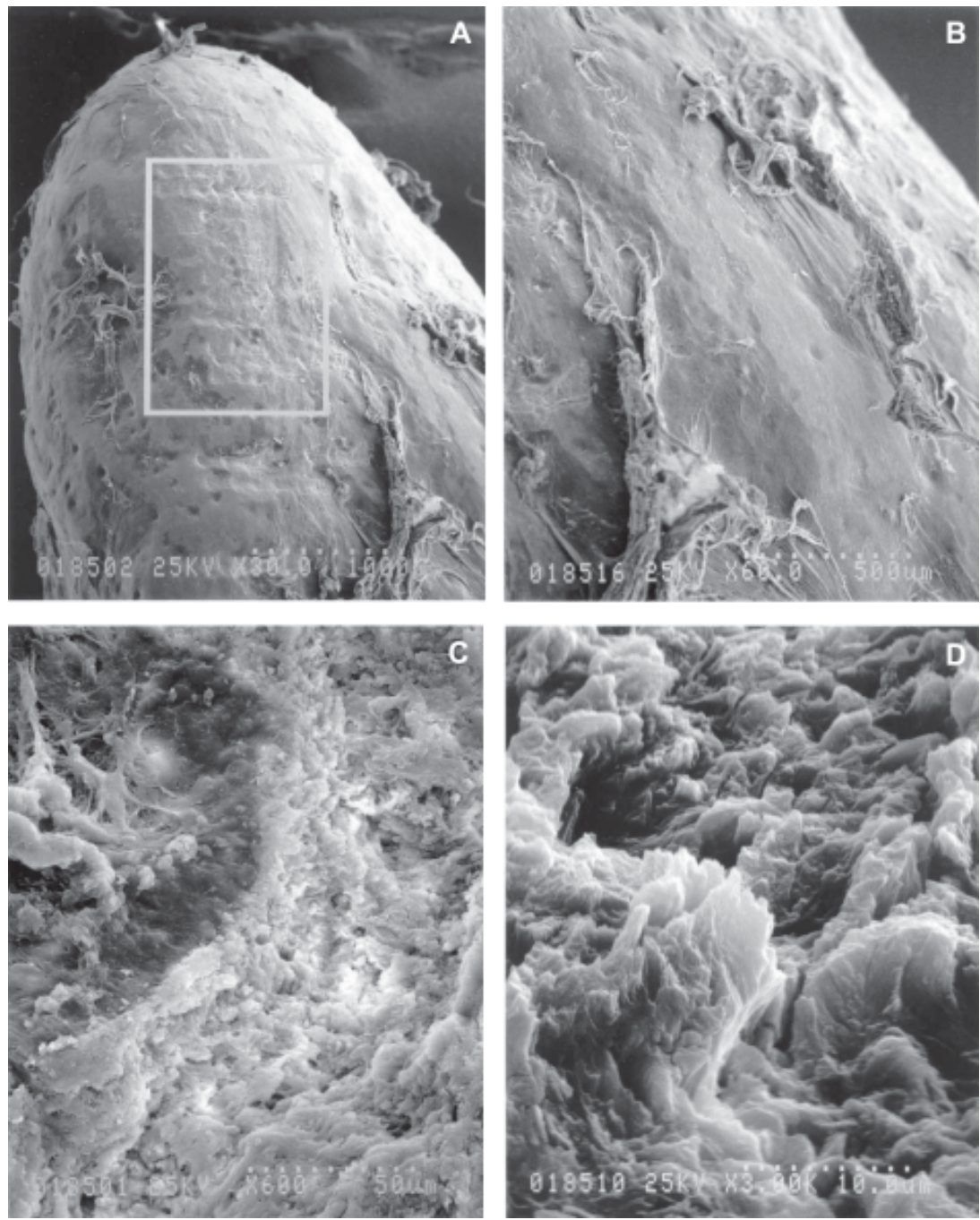

Figure 1. SEM micrographs of the apical root third of newly extracted teeth. A: Delimitation of the irradiated area (30X); B: Absence of periapical tissue on irradiated area (60X); C: Morphological changes on cementum surface, with slightly uneven surface formation (600X); D: High magnification (3000X) of an irradiated area, showing vaporization of apical biofilm and ablation of cementum surface, without exposure of dentin tubules. 
respond well to mechanical, chemo-pharmacological and irrigating procedures. Therefore, several methods using conventional intracanal therapy have been evaluated to provide a successful healing.

Microorganisms have been found in inflammatory periapical lesions $(14,15)$ and failure in endodontically retreated teeth with periradicular lesions are due to resistant microorganisms present in necrotic tissue adjacent to the apical foramen and root surface $(2,16,17)$.

Various reports quote periapical bacteria plaque or bacterial biofilm. Others consider bacteria a group of microorganisms comprising fungi, yeasts and bacteria. Treatment successful is achieved only with removal of the irritating agents (16). Surgical procedures, apicoectomy or apical curettage have been suggested due to inadequate eradication of microorganisms even after proper root canal treatment or retreatment. The goal of apical curettage is to eliminate infected tissues around the apex, but it is hard to know when the infected tissues have been completely removed with this technique. Failures following apicoectomy are associated with leakage and inadequately sealed retrograde fillings (18), and microorganisms remain near the resected area (6). The complete therapeutic procedure aims to eliminate apical periodontal infections with only access to the main root canal and the canal system.

In addition to intracanal procedures, laser irradia- tion has been presented as a promising method for providing morphological changes on dentin and cementum surfaces, as well as for biofilm removal.

Different types of dental lasers have been used to obtain successful results in the treatment of periapical lesion $(3,8,19)$. The Er:YAG laser has been recently introduced to dentistry and has potential for different clinical applications with excellent results. Studies have shown that dental hard substances can be removed by pulsed Er:YAG laser irradiation. The Er:YAG laser has attracted attention due to its capacity for ablating hard tissue with extremely small thermal effects $(16,20)$. The $2.94 \mu \mathrm{m}$ wavelength is highly absorbed by water and thus causes little damage on hard tissues. This laser causes minimal or no pain and induces little temperature rise, leading to safe clinical use.

The findings of this study showed that laser irradiation of contaminated apical areas allowed superficial vaporization of the attached microorganisms (Fig. 1-D), like in other clinically tested situations. Another favorable aspect was that the laser acted only on the contaminated cementum surface not reaching the underlying dentin.

In the irradiation, it is necessary to mention that both microbiological apical biofilm and infected cementum were vaporized creating a morphologically modified surface free of exposed dentin tubules.
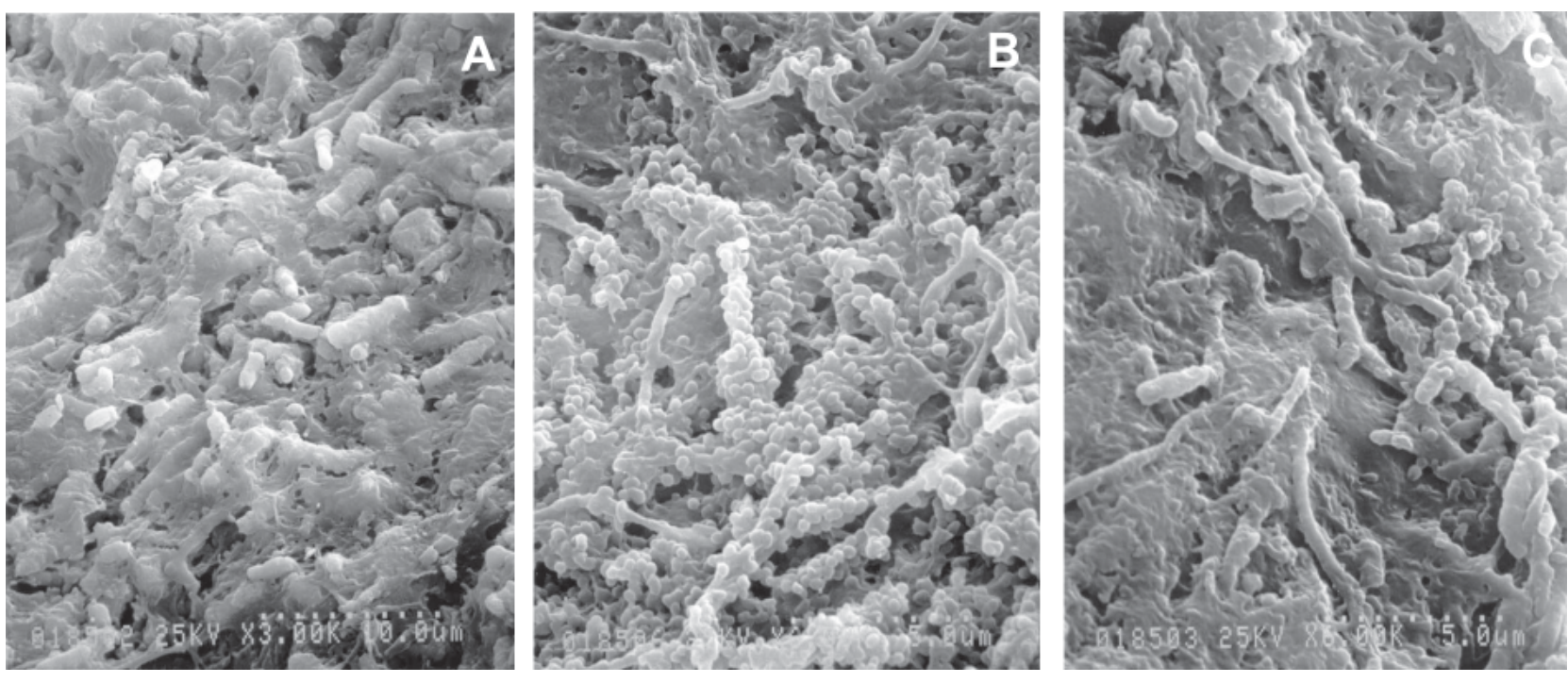

Figure 2. SEM micrographs of non-irradiated areas of the apical root third. A: Presence of microbiological apical biofilm (3000X); B: High magnification of the microbiological apical biofilm and presence of cocci (6000X); C: High magnification of the microbiological apical biofilm and presence of rods (6000X). 
The findings of the present study showed that the Er:YAG laser may be considered an effective tool for removal of apical biofilm. However, further research must be undertaken to evaluate its clinical use. The following conclusions may be drawn: 1) Removal of microbial apical biofilm from irradiated areas of root surface confirmed the potential of Erwin laser (Morita Co.'s Er:YAG laser device) for microorganism control; 2) Morphological changes with small roughened areas on cementum surface without dentin tubule exposure suggested that the contaminated or infected cementum had been vaporized; 3) Periodontal tissue on the apical surface of irradiated areas also seemed to have been vaporized.

\section{RESUMO}

A problemática dos casos envolvendo pacientes portadores de lesões periapicais resistentes é a eliminação da infecção que atinge a região periapical. Esta infecção é composta por microrganismos e seus subprodutos alojados no cemento e dentina do terço apical, sob forma de biofilme microbiano. A execução da cirurgia paraendodôntica com vistas à promoção da saúde do periápice, invariavelmente resume-se em remover mecanicamente os agentes causadores da doença, com objetivo de proporcionar a reparação. O propósito deste estudo foi avaliar o resultado da irradiação com laser de Er:YAG no terço apical de dentes recém extraídos com relação à infecção microbiana na superfície do ápice radicular. O laser Er:YAG foi empregado para irradiação de ápices radiculares, com ponteira experimental de contato (Chisel, Morita co.), utilizando energia de potência de $100 \mathrm{~mJ}, 10 \mathrm{~Hz}$, por 3 vezes em área delimitada no terço apical das raízes. Os resultados do estudo em microscopia eletrônica de varredura mostraram a eliminação do tecido periodontal remanescente juntamente com quantidade significativa de microrganismos. Portanto, pode-se concluir que o laser de Er:YAG nas condições experimentais testadas mostrou-se efetivo na remoção de microrganismos do tecido periodontal contaminado e do cemento sem expor a dentina subjacente.

\section{ACKNOWLEDGEMENTS}

The authors wish to thank the Department of Oral Surgery of Sapporo Medical University, the Department of Operative Dentistry and Endodontology of the Health Science University of Hokkaido and Mr. Ito Tsuguo from the Scanning Electron Microscopy Laboratory, of the Department of Endodontics at the University of São Paulo.

\section{REFERENCES}

1. Sundqvist G, Figdor D, Persson S, Sjögren U. Microbiologic analysis of teeth with failed endodontic treatment and outcome of conservative re-treatment. Oral Surg.Oral Med Oral Pathol Oral Radiol Endod 1998;85:86-93.
2. Tronstad L, Barnet F, Cervone F. Periapical bacterial plaque in teeth refractory to endodotic treatment. Endod Dent Traumatol 1990;6:73-77.

3. Noguchi N, Nori Y, Narimatsu M, Ebisu S. Identification and localization of extraradicular biofilm-forming bacteria associated with refractory endodontic pathogens. Appl Environ Microbiol 2005;71:8738-8743.

4. Lin LM, Gaengler P, Langeland K. Periradicular curettage. Int Endod J 1996;29:220-227.

5. Cheung GS. Endodontic failures - changing the approach. Int Dent J 1996;46:131-138.

6. Samaranayake LP, Stassen LF, Still DM. A microbiological study of pre- and postoperative apicoectomy sites. Clin Oral Investig 1997;1:77-80.

7. Allen RK, Newton CW, Brown Jr CE. A statistical analysis of surgical and nonsurgical endodontic retreatment cases. J Endod 1989;15:261-266.

8. Stern RH, Sognnaes RF. Laser beam effect on dental hard tissue. J Dent Res 1964;43:873 (Abstract).

9. Hibst R, Keller U. Experimental studies of the application of the Er:YAG laser on the dental hard substances: I. Measurement of the ablation rate. Lasers Surg Med 1989;9:338-344.

10. Komori T, Yokoyama K, Takato T, Matsumoto K. Clinical application of the Erbium YAG laser for apicoectomy. J Endod 1997;23:748-750.

11. Leonardo MR, Rossi MA, Silva LA, Ito IY, Bonifácio KC. EM evaluation of bacterial biofilm and microorganisms on apical external root surface on human teeth. J Endod 2002;28:815818.

12. Theodoro LH, Haypek P, Bachmann L, Garcia VG, Sampaio JE, Zezell DM, Eduardo CP. Effect of Er:YAG and diode laser irradiation on the root surface: morphological and thermal analysis. J Periodontol 2003;74:838-843

13. Watanabe H, Aoki A, Shikawa I. Clinical evaluation for scaling with newly developed Er:YAG laser. J Periodontol 1997;24:864.

14. Araki AT, Ibaraki Y, Lage-Marques JL, Kawakami T, Matsuda K, Kataoka K. Study on morphological changes of periapical cementum irradiated by Er:YAG laser. In: 6th International Congress on Laser in Dentistry. Maui, Hawaii, USA; 1998. Abstract \#95:48.

15. Tronstad L, Barnet F, Riso K, Slots J. Extraradicular endodontic infections. Endod Dent Traumatol 1987;3:86-90.

16. Lin LM, Pascon EA, Skribner J, Gaengler P, Langeland K. Clinical, radiographic and histopathological study of endodontic treatment failures. Oral Surgery Oral Med Oral Pathol 1991;71:603-611.

17. Loncali G, Sem BH, Cankaya H. Scanning electron microscopic observations of apical root surfaces of teeth with apical periodontitis. Endod Dent Traumatol 1996;12:70-76.

18. Stabholz A, Khayat A, Weeks DA, Neev J, Torabinejad M. Scanning Electron microscopic study of the apical dentine surface lased with Nd:YAG laser following apicoectomy and retrofill. Int Endod Traumatol 1992;25:288-291.

19. Aun CE, Lage-Marques JL, Gavini G, Clasen NF, Matsumoto K. Morphological analisis of retrofilled apical dentin surface irradiated with $\mathrm{CO}_{2}$ laser. The International Society of Optical Engineering (SPIE) Proceedings; 1998;3248:223-229.

20. Paghdiwala AF. Root resection of endodontically treated by erbium:YAG laser radiation. J Endod 1993;19:91-94.

Accepted August 30, 2006 